УДК 340.11(477)

\author{
Крестовська Наталія Миколаӥвна \\ доктор юридичних наук, професор, \\ Одеська начіональна юридична академія, \\ Одеса, Україна, \\ krestovska@i.ua
}

\title{
ДИТИНА І ЗБРОЯ: ІСТОРИКО-ПРАВОВІ АСПЕКТИ
}

Проаналізовано історичні факти залучення дітей до військової справи та участі дітей у збройних конфліктах. Зроблено висновки про відсутність норм щодо запобігання участі дітей у збройних конфліктах у докласичному міжнародному праві та надання захисту дітям лише в контексті захисту усіх некомбатантів у класичному міжнародному праві. У роки Першої та Другої світових війн виник феномен - дітей-солдат. Декларація прав дитини 1924 р. не створила дієвого механізму запобігання залученню дітей до збройного конфлікту. Ця мета була лише частково досягнута 3 прийняттям Четвертої Женевської конвенції 1949 р. та Додаткового протоколу № 1 до неї. Конвенція про права дитини та Факультативний протокол до неї щодо участі дітей у збройних конфліктах, Конвенція МОП № 182 та Римський Статут Міжнародного кримінального суду нині становлять механізм запобігання залученню дітей у збройний конфлікт. Запропоновано на національному рівні криміналізувати втягнення дітей у збройний конфлікт і ратифікувати Римський Статут Міжнародного кримінального суду задля притягнення довідповідальності осіб, винуватих у втягненні дітей у збройний конфлікт.

Ключові слова: дитина, збройний конфлікт, мілітаристське виховання, Факультативний протокол до Конвенції про права дитини щодо участі дітей у збройних конфліктах, Міжнародний кримінальний суд.

Krestovska Nataliia, Doctor of Juridical Sciences, Professor, Odesa National Academy of Law, Odesa, Ukraine

\section{The child and weapon: historical and legal aspects}

The author analyzes historical facts of involving children in military affairs and armed conflicts. The author comes to the conclusions that classical international law lacks rules on preventing the children involvement into armed conflicts and provides children protection only in the context of the non-combatants protection. During the Ist and IInd World Wars there arose such a phenomenon as children soldiers. Declaration of the Rights of the Child in 1924 did not created an effective mechanism for preventing the children involvement into armed conflicts. This goal was partially achieved only with the adoption of the 1949 Fourth Geneva Convention and Additional Protocol 1 to it. Convention on the Rights of the Child and its Optional 
Protocol on the children involvement into armed conflicts, ILO Convention № 182 and the Rome Statute of the International Criminal Court today constitute a mechanism preventing the involvement of children in armed conflicts. It is offered on nationally level to criminalize the involvement of children in armed conflicts and ratify the Rome Statute of the International Criminal Court for prosecution of persons accused of the children involvement in armed conflict.

Key words: child, armed conflict, militaristic education, the Optional Protocol to the Convention on the Rights of the Child on the involvement of children in armed conflict, the International Criminal Court.

Крестовская Наталья Николаевна, доктор юридических наук, профессор, Одесская национальная юридическая академия, Одесса, Украина

\section{Ребенок и оружие: историко-правовые аспекты}

Проанализированы исторические факты привлечения детей к военному делу и участия детей в вооруженных конфликтах. Сделаны выводы об отсутствии норм по предотвращению участия детей в вооруженных конфликтах в доклассическом международном праве и предоставления защиты детям только в контексте защиты всех некомбатантам в классическом международном праве. В годы Первой и Второй мировых войн возник феномен - детей-солдат. Декларация прав ребенка 1924 г. не создала действенного механизма предотвращения привлечению детей к вооруженному конфликту. Эта цель была частично достигнута с принятием четвертой Женевской конвенции 1949 г. и Дополнительного протокола № 1 к ней. Конвенция о правах ребенка и Факультативный протокол к ней, касающийся участия детей в вооруженных конфликтах, Конвенция МОТ № 182 и Римский Статут Международного уголовного суда в настоящее время составляют механизм предотвращения привлечению детей в вооруженный конфликт. Предложено на национальном уровне криминализировать вовлечение детей в вооруженный конфликт и ратифицировать Римский Статут Международного уголовного суда для привлечения к ответственности лиц, виновных в вовлечении детей $\mathrm{B}$ вооруженный конфликт.

Ключевые слова: ребенок, вооруженный конфликт, милитаристское воспитание, Факультативный протокол к Конвенции о правах ребенка, касающийся участия детей в вооруженных конфликтах, Международный уголовный суд.

Вступ та мета дослідження. Необхідність протистояння залученню дітей до збройного конфлікту є однією з проблем, з якою нині безпосередньо стикається українське суспільство. Зважаючи на те, що кожне соціальне явище має історичні коріння, звернення до витоків цієї проблеми задля кращого 
розуміння іï сутності та пошуку варіантів розв’язання видається доречним та своєчасним.

Аналіз попередніх досліджень. Історія розробки інституту захисту прав дітей під час збройних конфліктів у ХX ст. та сучасний його стан висвітлені у працях зарубіжних учених - Дж. Ван Бюрен (G. Van Bueren), М. Хапполда (M. Happold), Дж. Купер (J. Kuper), С. В. Тіфенбрун （S. W. Tiefenbrun), О. М. Старовойтова, українських учених: М. О. Баймуратова, О. І. Вінгловської, О. В. Скрипнюка, А. В. Пшеничної та інші. Тема дитини на війні піднімається у працях 3 історії дитинства, зокрема, у колективній монографії за редакцією Дж. Мартена (J. Marten) аналізується участь дітей в Американській революції, Громадянській війні у США, Першій та Другій світових війнах, сучасних війнах. Високо слід оцінити працю П. Щербініна щодо дитячої повсяденності у Росії часів Першої світової війни та О. Кучеренко щодо участі радянських дітей у Другій світовій війні. Разом із тим указані роботи не вичерпують тему дитини на війні та дитини зі зброєю, тим більше - ii історико-правові аспекти, що й зумовило тему цієї статті.

Викладення основного матеріалу. Варто відразу зробити застереження, що у найдавніші часи вік дитинства спливав набагато раніше досягнення вісімнадцяти років, що нині $\epsilon$ межею повноліття. Отже, й залучення до військової справи розпочиналося у ранньому дитинстві. Так, у Стародавньому Римі по досягненні хлопчиком семи років батько вчив його їздити верхи, метати спис та битися в повному військовому спорядженні [11, с. 153]. У стародавніх германців хлопчик набував цінності в очах суспільства тільки тоді, коли проявляв воїнську звитягу, а до того він жив поряд 3 рабами [84, с. 345]. Дитинство остаточно закінчувалося у той момент, коли особа могла тримати в руках зброю. Невипадково Салічна правда особливо високим штрафом охороняла життя хлопчика тільки до десяти років (титул XXIV § 1) [10, с. 78], бо старший за цей вік хлопець уже уважався таким, що може боронитися сам.

За часи середньовіччя військовий вишкіл хлопчиків 3 раннього дитинства став нормою для шляхетського стану. Діти на війні грали роль допоміжного персоналу, зокрема, зброєносців, вартових, слуг. Відомі й подвиги юних воїнів. Так, шістнадцятирічний Едуард Чорний принц командував правим флангом англійського війська у битві при Кресі. Коли його охоронці поспішили до короля-батька по допомогу, останній відповів: «Настав час юнаку заслужити свої шпори! Не приходьте до мене, допоки у нього будуть сили тримати в руці меч або пику!» [14, с. 305]. Не менш відважним воїном себе показав чотирнадцятирічний французький принц Філіп, який до кінця бився поряд 3 батьком - королем Іоанном Добрим у битві при Пуатьє.

Залучення до зброї дітей стало частиною військової політики Османської імперії. Султан Мурад I (1362-1389) започаткував девширме (данину кров'ю) 3 підкорених християнських народів: хлопчиків, які досягли семи років, 
вилучали із сімей, обертали на мусульман, і найкращих та найхоробріших з них віддавали на військове навчання, а в подальшому до війська (саме їх називали яничарами) [12, с. 28]. Така практика існувала до др. пол. XVI ст.

На сході Свропи простежуються подібні тенденції у використанні дітей в якості воїнів або допоміжного персоналу у війську. Так, Галицько-Волинський літопис згадує отроків, які тримали коней князівських дружинників під час битви (1232) [5, с. 390]. Військовий вишкіл юнаків проходив у Запорізькій Січі (джури), хоча маленькі діти на Січ, як і жінки, не допускалися.

Можна впевнено сказати, що за часи докласичного міжнародного права питання про особливу охорону дітей під час збройного конфлікту не ставилося, адже дитинство як соціальна цінність стародавнім спільнотам була невідома. I якщо можна говорити про захист дітей під час війни, то лише в контексті захисту усіх беззбройних осіб. Саме так варто трактувати положення «Божого миру», проголошеного синодом у Шарру (989), які зобов'язували майже безперервно воюючих феодальних суверенів не застосовувати зброю проти духовенства та бідноти, тобто проти тих станів, яким заборонено було володіти зброєю [16, с. 412].

Дві американські революції, наполеонівські війни та Кримська (Східна) війна явили світу нові приклади участі дітей у воєнних діях. Як влучно висловилася Е. Макміллан, діти ставали до війська поряд з батьками, замість батьків або всупереч батькам. Вона наводить приклади не тільки добровільного, але й примусового рекрутування до війська колоністів п'ятнадцятирічних i навіть дванадцятирічних хлопців [17, с. 20-21]. У французькій та англійській арміях XIX ст. хлопчики нерідко виступали як барабанщики або дударі (до винаходу телефону та радіо вони були важливою частиною системи зв'язку на полі битви). Як правило, до війська залучалися сини військовослужбовців або сироти, нерідко були й втікачі з дому, адже роль барабанщика видавалася дітям дуже привабливою.

У Росії залучення дітей до військової справи було дозволено на законодавчій основі. 3 петровських часів дворянських дітей записували на службу у певний полк, 3 тим, щоби 3 досягненням повноліття вони могли розпочинати службу не 3 самого низу кар'єрних сходів. Утім, $1763 \mathrm{p}$. обов'язкова служба для дворян була скасована при залишенні рекрутського набору для простолюду. У XIX ст., особливо після війн проти Наполеона, недоліки рекрутського набору стали очевидними. Через це царський уряд увів систему військових поселень, мешканці яких мали поєднувати військову службу 3 селянською працею та повинностями. Солдатські сини, а також кантоністи 3 числа євреїв та деяких ін. національностей навчалися військовому ремеслу 3 дитинства. Крім залучення до військового навчання неправославних дітейкантоністів примушували до зміни віросповідання. 
На кін. ХIX ст. попри уведення більшістю країн призовного віку або ін. вікових критеріїв служби у війську не існувало механізмів запобігання залученню дітей до збройного конфлікту. Захист дітей від негативних наслідків збройних конфліктів був складовою захисту всього цивільного населення, що знайшов своє відображення у конвенціях із міжнародного гуманітарного права. До преамбули Конвенції про закони та звичаї сухопутної війни (1899) було включено «застереження Мартенса», яке свідчило, що у випадках, не передбачених міжнародними угодами, цивільне населення i воюючі залишаються під захистом і дією принципів міжнародного права, оскільки вони випливають із встановлених між цивілізованими народами звичаїв та законів людяності та вимог суспільної свідомості. У Положенні про закони і звичаї сухопутної війни 1907 р. також містилися певні гарантії, які повинні надаватися цивільному населенню під час війни.

Перша світова війна послужила потужним поштовхом для розвитку міжнародного гуманітарного права. Проблема захисту прав дитини, яка на момент початку війни уже була поставлена і вирішувалася на законодавчому рівні у багатьох країнах Свропи та Америки, була загострена тим, що діти стали не тільки масовими жертвами, але й масовими учасниками війни. Діти 3 патріотичних мотивів і під впливом романтичних уявлень про війну втікали на театр воєнних дій. Ось деякі дані по Російській імперії. Протягом двох місяців 1915 р. поліція та жандарми на Південно-Західній залізниці затримали більше 200 дітей, з них 11 дівчаток, які прямували на фронт [6, с. 4]. Варто погодитися з висновком П. Щербініна, що саме в роки Першої світової війни виник особливий феномен - діти-солдати [15, с. 67], які ідентифікували себе не 3 дитячим, а з військовим колективом, відхиляли дитячі ігри на користь військового життя й позиціонували себе як захисники Вітчизни.

Війна спонукала до створення законодавства щодо захисту прав дітей під час збройних конфліктів. Серед таких нормативних актів Російської імперії слід назвати прийняте 2 вересня 1914 р. Положення про забезпечення дітей загиблих на війні осіб, які перебували у діючій армії та на флоті. Захист прав дітей було передбачено також законами щодо влаштування сімей, у т. ч. дітей солдат діючої армії та дітей загиблих солдат та офіцерів від 16 липня 1916 р. Зазначимо, що передовсім у цих законодавчих актах йшлося про матеріальну допомогу дітям - жертвам війни та їхнє влаштування у притулках. Проблема запобігання участі дітей у збройному конфлікті, зокрема, реагування та залучення їх до лав діючої армії та флоту не ставилася, а численні втікачі на фронт просто поверталися батькам.

Наслідки Першої світової війни зумовили постановку питання про особливий захист дітей на міжнародному рівні. У 1924 р. Ліга Націй ухвалила Декларацію прав дитини, за постановами якої саме діти мали бути першими, хто має отримувати допомогу під час будь-якої екстремальної ситуації, зокрема, 
збройного конфлікту. Утім, і Декларація 1924 р. не створила дієвого механізму запобігання залученню дітей до збройного конфлікту, що, серед ін. численних факторів, зумовило масову участь дітей у Другій світовій війні. Вони брали участь як у збройних силах країн антигітлерівської коаліції в та антифашистському русі Опору, так і виступали на боці країн Bici. О. Кучеренко, яка написала одну з небагатьох грунтовних праць про участь радянських дітей у війні, оцінює число неповнолітніх учасників війни з радянського боку у 60 тис. Вона вказує визначну роль, яку в масовому залученні дітей до зброї зіграло поєднання російських історичних традицій звеличення війни 3 комуністичною пропагандою [18, с. 54]. Дзеркальним ії відображенням була нацистська пропаганда, завдяки якій та завдяки примусовій мобілізації наприкінці війни до лав гітлерівської армії стало не менше 10 тис. неповнолітніх вояків 3 числа членів гітлерюгенду.

Але якщо у повоєнній Німеччині в ході денацифікації ідеї залучення дітей до мілітаризованих контрольованих державою організацій та готовності віддати життя за офіційно проголошену ідеологію було розвінчано, то в Радянському Союзі тему синів полку, юних партизан і підпільників, піонерів-героїв було зроблено частиною патріотичного виховання дітей та молоді, i, т. ч., залучення дітей до воєнних дій було не тільки апологізовано, але й глорифіковано.

Питання про спеціальний захист дітей у міжнародному гуманітарному праві було піднято після Другої світової війни. Інституційною складовою захисту дітей стало створення Дитячого фонду ООН, що, як передбачалося, протягом десяти років здатен буде подолати всі шкідливі для дітей наслідки війни. 1946 р. болівійське відділення Міжнародного Комітету Червоного Хреста запропонувало проект Конвенції про захист дітей у випадку міжнародного конфлікту або громадянської війни, але ця ідея була відхилена, а запропоновані норми включено до складу Четвертої Женевської конвенції 1949 р., присвяченої захисту цивільного населення під час війни. 17 статей цієї Конвенції так чи інакше стосуються дітей i саме вони надають не тільки загальний, але й спеціальний захист дітям, які перебувають на окупованих або не окупованих територіях під час збройного конфлікту. Женева-4 встановлювала декілька категорій дітей, які перебували під іiі захистом: діти до 7 років, до 15 років, до 18 років. Останніх, зокрема, заборонялося примушувати до праці на користь держави-окупанта. Утім, як указувала Дж. Ван Бюрен, цей акт не встановив нижньої вікової межі для легалізації участі дітей у збройних конфліктах [1, с. 394]. Це завдання було виконано Додатковим Протоколом № 1 до Женевських конвенцій 1977 р. Пункт 2 статті 77 зобов'язує сторони конфлікту вжити всі практично можливі заходи, щоб діти до 15 років не брали безпосередньої участі у воєнних діях, зокрема не підлягали вербуванню до збройних сил. При вербуванні до лав армії дітей, які досягли 15 , але не досягли 
18 років, сторона конфлікту зобов'язується віддавати перевагу дітям старшого віку [2].

Конвенція про права дитини, ратифікована майже усіма країнами світу, підтвердила положення Женеви-4 та Додаткового Протоколу № 1. I набагато далі пішла Конвенція МОП № 182, яка прирівняла вербування дітей для використання їх у збройних конфліктах до найгірших форм дитячої праці і зобов'язала країни-учасниці до викорінення цього ганебного явища [7]. Невідповідність рівня врегулювання правового захисту дітей під час збройних конфліктів викликам часу зумовила розроблення і відкриття до підписання Факультативного протоколу до Конвенції про права дитини, за яким державиучасниці мають вживати всіх можливих заходів для забезпечення того, щоб військовослужбовці їхніх збройних сил, які не досягли 18-ти річного віку, не брали прямої участі у воєнних діях, а також не підлягали обов'язковому призову до збройних сил. Заборона вербування або використання дітей у збройних конфліктах стосується і збройних груп, відмінних від збройних сил держави [13]. 2004 р. Україна ратифікувала цей протокол із заявою про недопущення за будь-яких умов участі неповнолітніх у збройних конфліктах i 2011 р. відзвітувала про його виконання. Крім того, 2007 р. Україна приєдналася до Паризьких зобов'язань щодо захисту дітей від незаконного вербування чи використання збройними силами або озброєними групами та Паризьких принципів і керівних вказівок щодо дітей, пов'язаних зі збройними силами чи озброєними угрупуваннями [4].

Одним із найстрашніших проявів збройного конфлікту на Сході України $\epsilon$ те, що нині до безпосередньої участі у воєнних діях залучаються діти. Неодноразово про це заявляли російські колаборанти, причому явно хизуючись такою підтримкою з боку населення [7, с. 79-80]. Але відомі й факти втягнення дітей у збройний конфлікт, в т. ч. у бойові зіткнення, і з боку урядових військ. За словами Президента України, за час проведення АТО на Донбасі, захищаючи Україну від російської агресії, загинув 21 неповнолітній [3].

Залучення дітей до збройного конфлікту на Сході України викликано, на нашу думку, низкою факторів. На перше місце варто поставити необізнаність і дітей, і дорослих про норми міжнародного гуманітарного права та ювенального законодавства України, які забороняють залучати дітей до будь-яких видів воєнної активності, включно й до допоміжної (доставляння боєприпасів, пошти, або харчів на лінію зіткнення, участь у будуванні оборонних споруд тощо), і до навчальної (тренування зі зброєю). Другим фактором, який проявляється на непідконтрольних українському уряду територіях Донецької та Луганської області, є відновлення окупаційною владою та колаборантами радянських зразків і мілітаристського виховання дітей та молоді. Певну роль відіграє й скрутне економічне становище молоді. Так, неповнолітній, засуджений за участь у не передбаченому законом збройному формуванні (ст. 260 КК України), 
пояснив, що після закінчення училища намагався знайти роботу, але марно, тому й вступив до злочинного угруповання «ДНР» [8]. Отже, проблема запобігання участі дітей у збройному конфлікті в Україні досі не тільки не вирішена, але й загострена.

Висновки. На наше глибоке переконання, цю проблему слід вирішувати у правовий спосіб, що підтверджується наведеними вище результатами історико-правового дослідження. Відсутність адекватного викликам часу правового регулювання, зокрема, чітко встановленої заборони втягувати дітей у збройний конфлікт та механізму притягнення винуватих у порушенні цієї заборони осіб до юридичної відповідальності, зумовила, серед ін. чинників, масову участь дітей у збройних конфліктах XX ст.

По-перше, варто привести національне законодавство у сувору відповідність до Факультативного протоколу до Конвенції про права дитини щодо участі дітей у збройних конфліктах. Чинне кримінальне законодавство досі не містить відповідних норм щодо покарання осіб, винних у втягуванні дітей у збройних конфлікт та воєнні дії. По-друге, позитивну роль у захисті прав дитини під час збройного конфлікту зіграла би ратифікація Верховною Радою України Римського Статуту, який поширює юрисдикцію Міжнародного кримінального суду на злочини проти дітей, вчинені у ході збройних конфліктів. Красномовним фактом $є$ те, що Міжнародним кримінальним судом за залучення дітей до збройного конфлікту було винесено перший в його історії обвинувальний вирок: конголезець Томас Лубанга Дьїло був ув'язнений на строк 14 років за вербування дітей до підконтрольних йому збройних угруповань. По-третє, необхідно розгорнути просвітницьку роботу серед дітей, ïx батьків, військового та освітянського персоналу 3 метою засвоєння та подальшого використання ними норм міжнародного гуманітарного права щодо недопущення участі дітей у збройних конфліктах. До цієї справи варто залучити не тільки державні інституції, відповідальні за реалізацію ювенальної політики держави, але й міжнародні організації, зокрема МКЧХ та його національні структури, громадські організації, професійне юридичне співтовариство. Комплексний підхід до подолання нового для України суспільно небезпечного явища, яким є участь дітей у збройному конфлікті, здатен дати швидкі позитивні результати i знешкодити величезну загрозу охоронюваній правом України цінності - дитинства.

\section{Список використаних джерел:}

1. Б’юрен Дж. Міжнародне право в галузі прав дитини / Дж. Ван Бюрен ; пер. 3 англ. Г. Є. Краснокутського. - Одеса: БАХВА, 2006. - 524 с.

2. Додатковий протокол до Женевських конвенцій від 12 серпня 1949 р., що стосується захисту жертв міжнародних збройних конфліктів [Електронний pecypc]: $\quad$ (протокол $\quad$ I). 
http://zakon4.rada.gov.ua/laws/show/995_199. - Назва з екрану. - Дата звернення 25.02.2017.

3. За час АТО загинув 21 неповнолітній боєць - Порошенко [Електронний ресурс] // Центр інформації про права людини. - Режим доступу: https://humanrights.org.ua/material/za_chas_ato_zaginuv_21_nepovnolitnij_vijskovos luzhbovec_poroshenko. - Назва з екрану. - Дата звернення 25.02.2017.

4. Корнелий Т. О происхождении германцев и местоположении Германии / Тацит Корнелий // Сочинения: в 2 т. - Москва, 1993. - Т. 1. - С. $337-$ 355.

5. Літопис руський / відп. ред. О. В. Мишанич ; за іпат. списком пер. Л. Махновець. - Київ: Дніпро, 1989. - 590 с.: іл. - (Давньоруські та давні українські літописи).

6. Неделя войны // Родина (прил. к журн.). - 1915. - № 11. - С. 4.

7. Про ратифікацію Конвенції Міжнародної організації праці № 182 «Про заборону та негайні заходи щодо ліквідації найгірших форм дитячої праці»: Закон України від 05.10.2000 // Відомості Верховної Ради України. - 2000. № 48. - ст. 412.

8. Провадження № 1-кп/235/256/16, Сдиний унікальний № 235/9951/15-к, [Електронний ресурс]: вирок Красноарм. міськрайон. суду Донец. обл. 20 квіт. 2016 р. - Режим доступу: http://www.reyestr.court.gov.ua/Review/57287047. Назва з екрану. - Дата звернення 23.02.2017.

9. Пшеничная А. В. Проблемы обеспечения прав ребёнка в условиях вооружённого конфликта: современные вызовы для органов власти Украины / А. В. Пшеничная // Закон и жизнь. - 2015. - № 5/4. - С. 77-81.

10. Салическая Правда: учеб. лит. / пер. Н. П. Грацианского ; под ред. В. Ф. Семенова. - Москва: Образцовая тип. им. Жданова, 1950. - 168 с. (Ученые записки МГПИ им. В. И. Ленина ; т. 62).

11. Сергиенко М. Е. Жизнь древнего Рима. Очерки быта / М. Е. Сергиенко. - Москва ; Ленинград: Наука, 1964. - 336 с.

12. Срібняк I. Яничарський корпус османської армії (1362 р.-кінець XVI ст.) / І. Срібняк // Україна в Центрально-Східній Європі. - 2010. - С. 26-41.

13. Факультативний протокол до Конвенції про права дитини щодо участі дітей у збройних конфліктах: Ратифіковано із заявою Законом № 1845-IV від 23.06.2004 // Відомості Верховної Ради України. - 2004. - № 38. - Ст. 476.

14. Фруассар Ж. Хроники 1340-1350 / Ж. Фруассар ; пер. и прим. М. В. Аникеева. - Санкт-Петербург: РХГА: Ювента, 2012. - 856 с.

15. Щербинин П. П. Детская повседневность в период первой мировой войны 1914-1918 гг.: монография / П. П. Щербинин. - Тамбов, 2015. - 256 с.

16. A Source Book for Medieval History: Selected Documents Illustrating the History of Europe in the Middle Age. - New York: Scribners 1905. - 665 p. 
17. Children and War: A Historical Anthology / J. Marten, ed. - New York: New York University Press, 2002. - 309 p.

18. Kucherenko O. Little Soldiers: How Soviet Children Went to War, 19411945 / O. Kucherenko. - Oxford: Oxford U.P., 2011. - 266 p.

19. The Paris Principles. Principles and Guidelines on Children Associated with Armed Forces or Armed Groups [Electronic resource]. - Code of access: http://www.unicef.org/emerg/files/ParisPrinciples310107English.pdf. - Last access: 20.02.2017. - Title from the screen.

\section{References:}

1. Buren Van, J. (2006). International law in the field on the rights of the child. Translated from English by H. Krasnokutskyi. Odesa: BAKHVA.

2. Protocol Additional to the Geneva Conventions of 12 August 1949, and relating to the Protection of Victims of International Armed Conflicts (Protocol I) [online] Available at: http://zakon4.rada.gov.ua/laws/show/995_199. [Accessed 25 February 2017]. Title from the screen.

3. During the ATO 21 minors were killed - Poroshenko. Center for Human Rights Information. [online] Availiable at: https://humanrights.org.ua/material/za_chas_ato_zaginuv_21_nepovnolitnij_vijskovos luzhbovec_poroshenko. [Accessed 25 February 2017]. Title from the screen.

4. Tacit, K. (1993). On the origin of the Germans and the location of Germany, Vol. 1. Moscow.

5. Myshanych, O.V. ed. (1989). Russian chronicles. Translated from Old Russian by L. Makhnovets. Kyiv: Dnipro.

6. Week of war. (1915). Rodyna (prylozhenye $k$ zhurnalu) [Homeland (appendix to the magazine)], no, 11, p. 4.

7. On ratification of the ILO Convention No.182 On the Prohibition and Immediate Action for the Elimination of the Worst Forms of Child Labor (1999, June 17). (2000). Vidomosti Verkhovnoi Rady Ukrainy [Information from the Verkhovna Rada of Ukraine], no. 48, art. 412.

8. Proceedings No. 1-kp / 235/256/16, Unique unique No. 235/9951/15-k, Verdict of the Krasnoarmeysk district court of Donetsk region on April 20, 2016 [online] Available at: http://www.reyestr.court.gov.ua/Review/57287047. [Accessed 23 February 2017]. Title from the screen.

9. Pshenichnaja, A.V. (2015). Problems of ensuring the rights of the child in conditions of armed conflict: modern challenges for the Ukrainian authorities. Zakon $i$ zhizn [Law and Life], no. 5/4, pp. 77-81.

10. Semenov, V.F. ed. (1950). Salic law. Translated by N.P. Gracianskij. Moscow: an exemplary printing house named after Zhdanov.

11. Sergienko, M.E. (1964). The life of ancient Rome. Essays on life. Moscow, Lenigrad: Nauka. 
12. Sribniak, I. (2010). Janicharsky Corps of the Ottoman Army (1362 - the end of the seventeenth century). Ukraina v Tsentralino-Skhidnii Yevropi [Ukraine in Central and Eastern Europe], issue 9-10, pp. 26-41.

13. Optional Protocol to the Convention on the Rights of the Child on the Participation of Children in Armed Conflict: Ratified with a statement by Law No. 1845 IV of June 23, 2004. (2004). Vidomosti Verkhovnoi Rady Ukrainy [Information from the Verkhovna Rada of Ukraine], no 38, art. 476.

14. Froissart, J. (2012). The Chronicles of 1340-1350. Translated by M.V. Anikeev. St. Petersburg: RHGA; Juventa.

15. Shherbinin, P.P. (2015). Children's daily routine during the First World War of 1914-1918: monography. Tambov.

16. A Source Book for Medieval History: Selected Documents Illustrating the History of Europe in the Middle Age. (1905). New York: Scribners.

17. Marten, J. ed. (2002). Children and War: A Historical Anthology. New York: New York University Press.

18. Kucherenko, O. (2011). Little Soldiers: How Soviet Children Went to War, 1941-1945. Oxford: Oxford U.P.

19. The Paris Principles. Principles and Guidelines on Children Associated with Armed Forces or Armed Groups [online] Availiable at: http://www.unicef.org/emerg/files/ParisPrinciples310107English.pdf. [Accessed 20 February 2017]. Title from the screen.

() Крестовська Н. М., 2018 